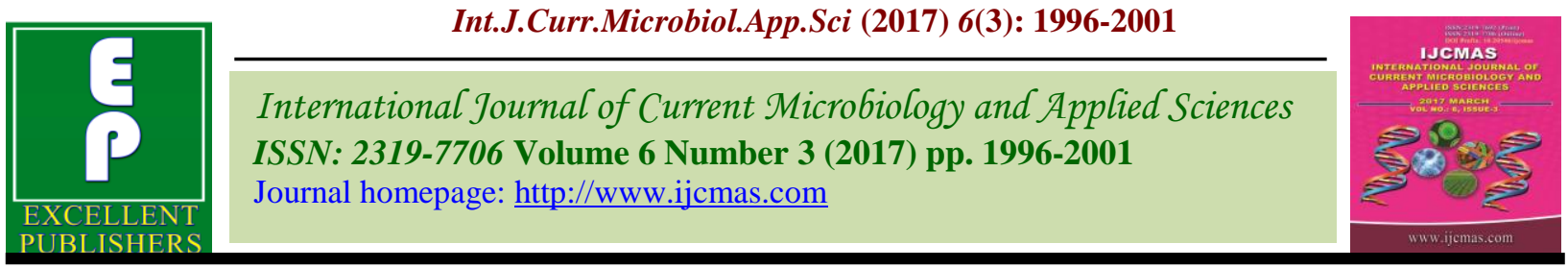

Original Research Article

https://doi.org/10.20546/ijcmas.2017.603.227

\title{
Soil Conservation Methods and Revegetation of Trans-Himalayan Cold Desert Region-Ladakh
}

\author{
Phuntsog Tundup ${ }^{1 *}$, M.A. Wani ${ }^{1}$, Sonam Dawa ${ }^{2}$ and Ngawang Dorjay ${ }^{3}$ \\ ${ }^{1}$ Division of Soil Science, SKUAST-K, Shalimar-190025, India \\ ${ }^{2}$ Division of Fricultue, SKUAST-K, Shalimar-190025, India \\ ${ }^{3}$ CAZRI, Leh Ladakh, India \\ *Corresponding author
}

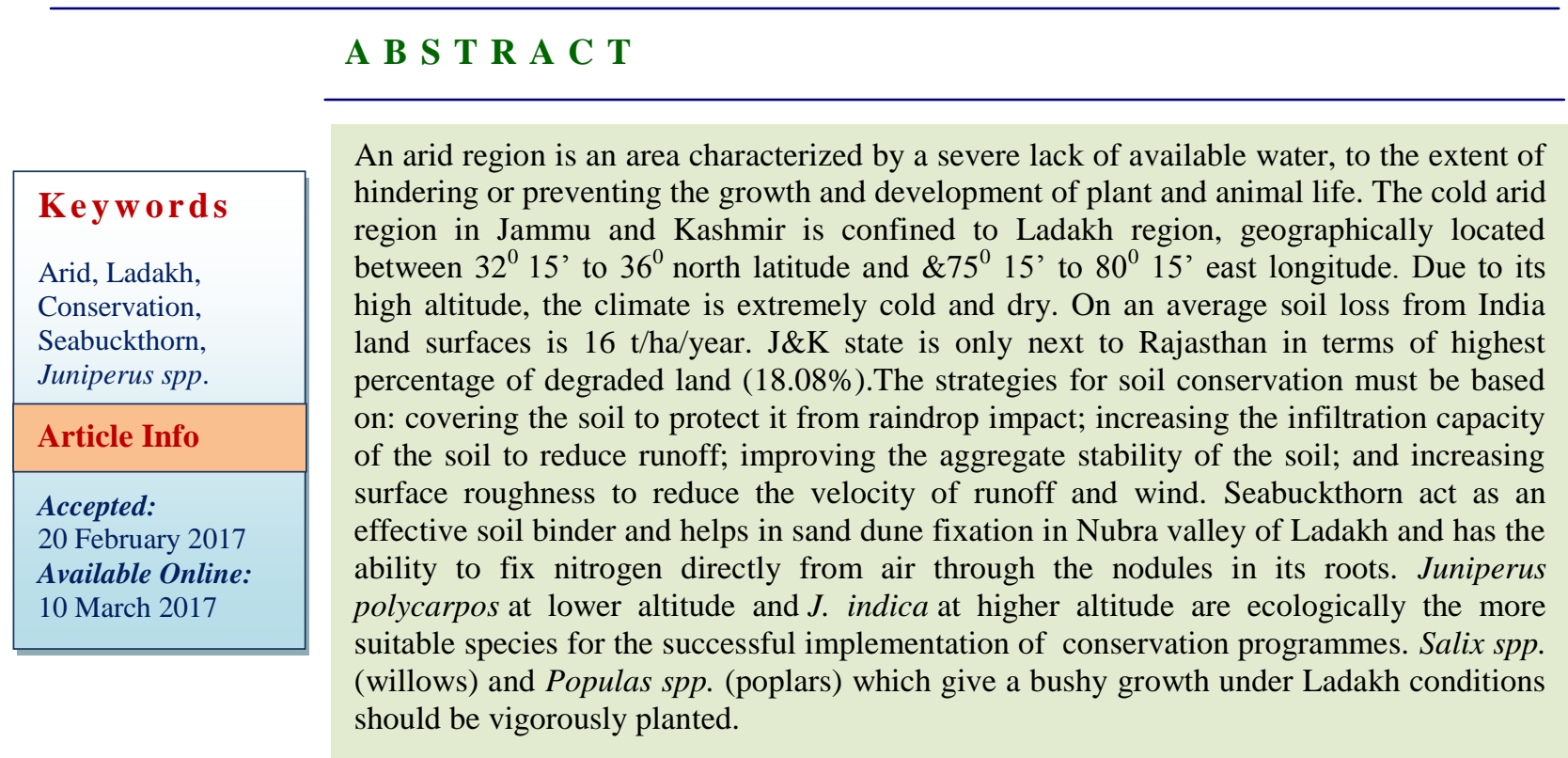

\section{Introduction}

The cold arid region in Jammu and Kashmir is confined to Ladakh region, geographically located between $32^{0} 15^{\prime}$ to $36^{\circ}$ north latitude and $\& 75^{\circ} 15^{\prime}$ to $80^{\circ} 15^{\prime}$ east longitude (Sharma, 2000). It covers approximately 82,665 sq. $\mathrm{Km}$ area of which 37,555 sq. Km. is under illegal occupation of Pakistan and China (SKUAST, 1998). Hence, area with India is 45,110 sq. $\mathrm{Km}$, representing 87.4 percent of total cold arid region. However, arable land is small and scattered in small pockets (Sharma and Mir, 2000). Barley (Hordeum vulgare), wheat (Triticum aestivum and alfalfa (Medicago sativa) are major crops, which cover $83 \%$ of the total cultivated area.

On an average, soil loss from land surfaces in India is $16 \mathrm{t} / \mathrm{ha} / \mathrm{year}$. Several thematic maps, such as soil depth, texture, drainage, available water capacity, erosion, $\mathrm{pH}$, etc. of Jammu and Kashmir have been generated using the master soil resource map and data base. Jammu and Kashmir is the only state next to Rajasthan in terms of highest percentage of degraded lands in India (18.08\%). About 7 million ha (31.6 per cent) area is affected by 
various soil degradation problems. The most serious problem is of water erosion, causing loss of top soil and/or terrain deformation, and has affected 24.6 per cent area. Wind erosion has been observed in Ladakh and an area of $1.4 \mathrm{~m}$ ha constituting about 6.1 per cent of the total growing area. Water logging and flooding has affected only 0.9 per cent of total growing area. From a normal covered forest, soil is eroded at an average rate of 1 to 4 t/ha/year (NBSS \& LUP, 2007). The waste lands of the cold desert of Ladakh was further aggravated owing to floods during August 18, 2006 and between the nights of August 5 and 6,2010 . The incessant rains in the cold desert of Ladakh on August 18, 2006 and cloud bursts triggered floods which caused wide spread damage not only to wastelands but also to agricultural lands and buildings (Gupta et al., 2012) vis-a- vis loss of human lives. Hence, an attempt was made to assess the status and potential of new and modern methods for conserving the valuable resource of the cold desert i.e. soil.

\section{Materials and Methods}

Ladakh has an extremely harsh environment and one of the highest and driest inhabited places on earth. Ladakh's climate is referred to as a "cold desert" climate due to its combined features of arctic and desert climates. These include wide diurnal and seasonal fluctuations in temperature, from $40^{\circ} \mathrm{C}$ in winter to $+35^{\circ} \mathrm{C}$ in summer, and extremely low precipitation, with an annual $10 \mathrm{~cm}$ to $30 \mathrm{~cm}$ primarily from snow (Demenge, 2006). Due to high altitude and low humidity, the radiation level is amongst the highest in the world (up to 6-7 Kwh/mm). The soil is thin, sandy and porous. These combined factors explain why the entire area is nearly devoid of vegetation, with the exception of valley floors and irrigated areas (Demenge, 2006).
The survey on the status and potential of green vegetation and/or different new methods for soil conservation was conducted in Leh and Kargil districts of J\&K. Ten villages from Leh district (Stakna, Phey, Skurbuchan, Achinathang, Domkhar, DhaBeema, Khaltsi, Nimmo, Basgo, Saspol) which are located around the famous river, Indus and five villages like Hardass, Sanjaq, Batalik, Trespon and Saliskot in Kargil district located near L.O.C which remains land locked for more than six months in a year, were purposively selected and the investigations were made through multiple field visits, questionnaires and interviews with elderly people.

\section{Results and Discussion}

Because of the geographical factors, the land of cold desert of Ladakh is devoid of moisture and generally wears a deserted look and has zero vegetation at the higher elevations. So, the details of the present investigation carried out to study the status of different methods of soil conservation and revegetation in high altitude zones of cold desert himalayas is presented hereunder.

\section{Pasture development}

Pasture offer one of the most effective and economical means of holding and enriching the soil provided they are properly developed and managed. Two outstanding requirements of good management area are:

1. A sufficient supply of mineral plant nutrients such as lime, phosphorous and potash for desirable pasture plants to make enough growth to cover and protect the soil and to provide forage for livestock.

2. Regulation of the number and kind of livestock and the periods of grazing so that the pasture plants can make a vigorous growth during the grazing season. 
When sloping land is kept with good pasture, the wastage of soil is stopped and its productivity is increased. They also provide the most effective cover for soil and water conservation and provide good protection to bunds, terrace and also reduce runoff. The region (Ladakh) has a tremendous potential for pasture development. Right from Zogila to Drass and beyond the area can be develop into good pasture belt. In Drass farm, Red clover, Tall fescue, Dactylus glomerata, alfa alfa, oats had given a good performance and Red clover was excellent. Clover and alfa alfa are also doing well in Leh.

Overgrazing or heavy grazing is a major constraint to pasture development. Vegetation is destroyed by the trampling and the bare ground is pounded, powdered or puddled by the hooves of herds. When rain comes, the erosion is accelerated as the soil gets loosened. Heavy grazing also removes the leaves of grasses, curtailing photosynthesis and seeding. To overcome the bad effects of overgrazing especially in the Changthang area of Leh district, where world known Pashmina goat are present, rotational grazing should be followed which is almost essential on severely depleted pasture where erosion and soil loss are serious.

\section{Bio-engineering methods}

Wattling and staking method: Wattles, also termed fascines, are cigar-shaped bundles of six to eight live cuttings, each $200-250 \mathrm{~mm}$ in diameter, arranged with butt ends alternating, and tied at 300-400mm intervals (Figure 1).

Species that root easily are used, such as Salix, Leucaena, Baccharis and Tamarix. The wattles are placed in shallow trenches on the contour, $0.3 \mathrm{~m}$ wide, up to $0.5 \mathrm{~m}$ deep and spaced at $4 \mathrm{~m}$ intervals on slopes less than $30^{\circ}$ and at $2 \mathrm{~m}$ intervals on slopes of $30-45^{\circ}$. The lines where the fascines will be installed are marked out on the slope. Then, starting from the bottom of the slope, $5 \mathrm{~m}$ lengths of trench, $100 \mathrm{~mm}$ deep and $200 \mathrm{~mm}$ wide, are dug at any one time. The fascines are placed in the trench, covered with soil so that about 10 per cent of the fascine is exposed and pegged to the slope at $0.5-0.8 \mathrm{~m}$ intervals using wooden stakes, $0.6 \mathrm{~m}$ long, driven vertically into the ground. Grasses and shrubs can be planted between the wattles.

Brush matting: Brush mats can be used as an alternative to geotextiles to provide an immediate cover to the slope and prevent surface erosion. Since they also provide the basis for the long-term vegetation cover, they are only suitable for sites where the species used is appropriate as the final land cover. With brush matting, cuttings of stems and branches of live willow are placed on the slope, butt ends downslope, at 20-50 stems per running metre, to give a minimum of 80 per cent ground cover (Schiechtl \& Stern 1996). The thicker ends of the branches are covered with soil to aid rooting and then fixed with stones or pegs. The whole is covered with soil and the brush fixed to the slope using stakes or wires.

\section{Planting trees and shrubs:}

Seabuckthorn- A magic plant for dry mountains: Seabuckthorn (Hippophae spp) is a deciduous shrub, widely distributed throughout the temperate zones of Asia and Europe and the subtropical zones of Asia at high altitudes. It is commonly found throughout the countries of the Hind-Kush Himalayan region. It has a highly developed root system, which is excellent for holding soils on a fragile slope. In seabuckthornplanted areas, loss of topsoil caused by seasonal monsoons can decrease to less than 30 per cent, and it is possible to hold more than 80 per cent of water in the ground. 
Table.1 Accumulated infiltration within 30 minutes in a rainfall

\begin{tabular}{|l|c|c|c|}
\hline Landform unit & $\begin{array}{c}\text { Seabuckthorn forest } \\
(\mathbf{m m})\end{array}$ & $\begin{array}{c}\text { Waste grassland } \\
(\mathbf{m m})\end{array}$ & $\begin{array}{c}\text { Farmland } \\
(\mathbf{m m})\end{array}$ \\
\hline Slope bottom & 131.788 & 59.890 & 64.487 \\
\hline Slope top & 205.425 & 62.642 & 75.266 \\
\hline
\end{tabular}

Source: Acharya et al., 2010

Figure.1 Installation of wattles for slope stabilization

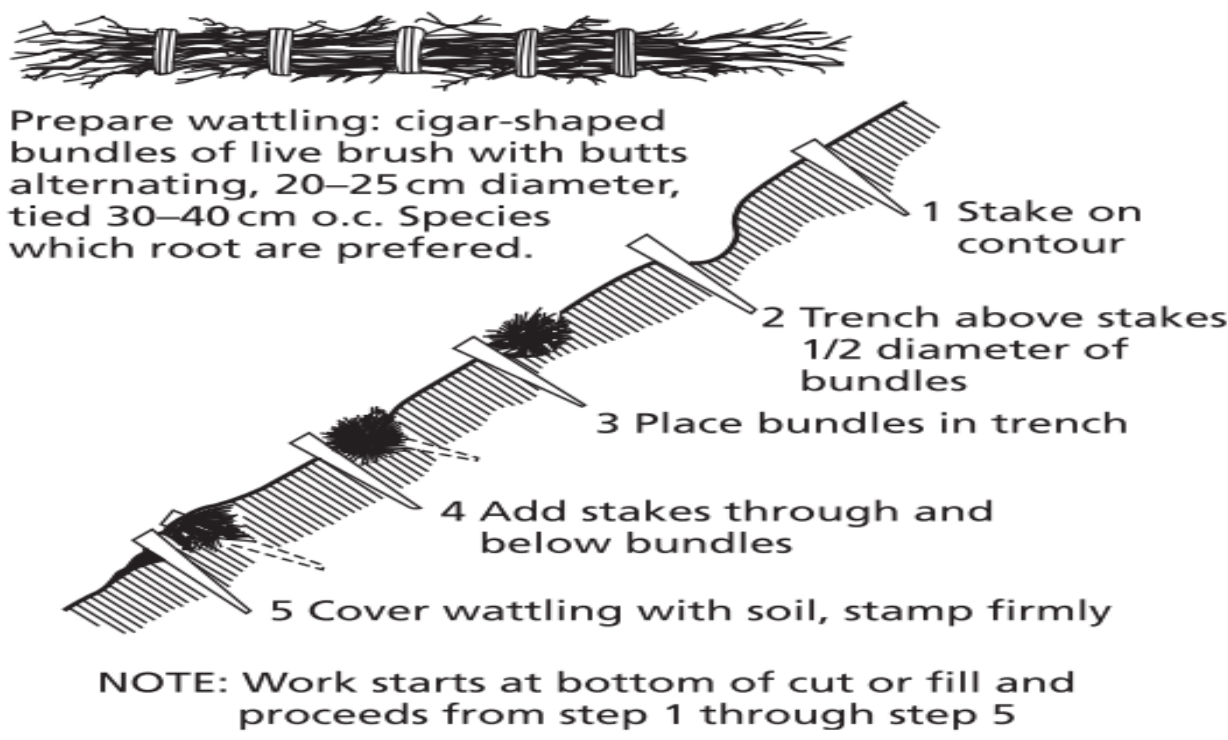

Source: Gray \& Leiser, 1982

Seabuckthorn has the ability to take root even in poor soils, because it can fix nitrogen directly from air through the nodules in its roots. A natural seabuckthorn forest can yield 750 to $1,500 \mathrm{~kg}$ of berries per hectare. Its fruit is a rich source of vitamins. Oil from the pulp and seeds is valued for its medicinal properties. It supplies palatable forage to all classes of livestock during most of the year.

Seabuckthorn is the only dominant woody plant of this region. It has been reported that Seabuckthorn is growing in Indus, Nubra, Zanskar and Suru valley of Ladakh region. It grows well on the riverbeds and mountain slopes upto 4,200 m above msl. Satellite imagery conducted by DIHAR, DRDO in collaboration with Defence electronics Application Laboratory, DRDO, Dehradun has found about 11,500 ha under pure
Seabuckthorn sand and 30,000 ha under mixed forest plantation in the Ladakh region (Dwivedi et al. 2003).

Seabuckthorn as erosion control: Seabuckthorn can stabilize slope, reduce surface runoff and streamflow, formed by rainstorm. Therefore it can change the runoff and sediment transportation characteristics. Together with the change of slope, land tillage method and engineering works in slope and gully, soil erosion may be controlled.

The developed root system of Seabuckthorn has formed an underground big biomass. Roots of a three year old Seabuckthorn can expand about $6 \mathrm{~m}$ in horizontal level direction and over $2 \mathrm{~m}$ in vertical direction (Acharya $e t$ al., 2010 ). 
Seabuckthorn has the ability to take root even in poor soils, because it can fix nitrogen directly from air through the nodules in its roots (Hafeez, 1999). Various studies clearly proved the function of sediment retention by Seabuckthorn (Table 1).

Afforestation: Tree planting has played a pivotal role in renewing the battered landscape of many of the world's arid areas (Ginsberg, 2000). Afforestation can conserve soil on degraded land by reducing soil erosion (Oscar, 2001), increasing soil organic matter, improving the soil structure, sequestering $\mathrm{C}$ and promoting the livelihood of farmers by permitting agroforestry that can reduce the pressure on forested lands (Cao et al, 2008 ).

The juniper species Juniperus polycarpos , $J$. indica and J. communis var. saxatilis (Pallas) are important elements of the forest vegetation in Lahaul valley in the northwestern Himalaya. Their ability to grow under the barren and xeric conditions of cold deserts makes them particularly suited for afforestation programmes under these ecological conditions. The rapid loss of vegetation due to overuse and habitat degradation has made the conservation of juniper forests an important priority in the Lahaul valley. $J$. polycarpos at lower altitude and $J$. indica at higher altitude are ecologically the more suitable species for the successful implementation of conservation programmes (Rawat and Everson, 2012).

These species of Juniperus can also be grown in Ladakh as the climate and others environmental factors are almost similar to that of Lahaul Spiti (Himachal Pradesh).

It can be concluded from the above discussion that the cold desert region of India i,e. ladakh has known to be cold desert which features scanty erratic rainfall and most of the geographical area were dry barren lands. To eradicate such naked barren land problems, few but effective new and advanced methods were evolved;

The most promising tool for soil conservation in cold arid is re-vegetation and seabuckthorn is one of the species sucessfully could be used on large scale.

New bio-engineering methods like wattling and staking, Brush matting etc. can be successfully used.

Afforestation with willows, poplar and Juniperus spp.

Awareness among the farmers about the conservation techniques.

\section{Acknowledgement}

The author would like to express his gratitude to the DIHAR (DRDO), KVK, Leh (SKUAST), J\&K Department of soil conservation and the farmers of Leh and Kargil districts for their valuable help and contribution beside moral support.

\section{References}

Acharya, S., Stobdan, T. and Singh, S.B. (2010). Seabuckthorn (Hippophae sp. L.): New crop opportunity for biodiversity conservation in cold arid Trans-Himalayas. J. soil water conser., 9(3): 201-204.

Cao, S., Chen, L., Liu, Z. and Wang, G. (2008). A new tree-planting technique to improve tree survival and growth on steep and arid land in the Loess Plateau of China. J. Arid Environ. 72: 1374-1382.

Demenge, J. (2006). Measuring Ecological Footprints of Subsistence Farmers in 100 Ladakh, IDS, UK, pp. 1-31.

Dwivedi, S.K., Singh, R. and Raut, B. (2003). Studies on distribution of Seabuckthorn through remote sensing and its genetic diversity in Ladakh. 
International congress on Seabuckthorn. Berlin, Germany, 14-18 september, pp. 29.

Ginsberg, P. (2000). Man-made forestation in Israel: a source of social goods and services. Soc. American Fores., 98(3): 32-36.

Gray, D.H. and Leiser, A.T. (1982). Biotechnical slope protection and erosion control. Van Nostrand Reinhold, New York.

Gupta, P., Khanna, A. and Majumdar, S. (2012). Disaster Management in Flash Floods in Leh (Ladakh): A Case Study. Indian J. Comm. Med., 37(3): 185-190.

Hafeez, S. (1999). Selected technologies for land and soil management in the cold and dry regions of the Hindu KushHimalayas. Aridlands, 46: 67-70.

NBSS\&LUP. (2007). Soil Resource Mapping of States in Northern Region, National Bureau of Soil Survey and Land Use Planning (NBSS\&LUP), Research center, New Dehli, India.

Oscar, C. (2001). An analysis of externalities in agroforestry systems in the presence of land degradation. Ecological Economics 39: 131-143.

Rawat, Y.S. and Everson, C.S. (2012). Ecological status and uses of Juniper species in the cold desert environment of the Lahaul valley, North western Himalaya, India. J. Mountain Sci., 9: 676-686.

Schiechtl, H.M. and Stern, R. (1996). Ground bioengineering techniques for slope protection and erosion control. Blackwell Science, Oxford.

Sharma, J.P. and Mir, A.A. (2000). Dynamics of cold arid agriculture. Kalyani publisher, New Delhi, India.

Sharma, J. (2000). Cold arid agriculture: A bird's - Eye view from Dynamics of Cold Arid Agriculture, (Jagpul Sharma and A Aziz Mir, Eds), Kalyani Publishers, Ludhiana, pp. 3-15.

SKUAST. (1998). KVK Leh annual progress report 1997-98 and action plan 199899 from DEE SKUAST, RARS, Leh, pp. 32.

\section{How to cite this article:}

Phuntsog Tundup, M.A. Wani, Sonam Dawa and Ngawang Dorjay. 2017. Soil Conservation Methods and Revegetation of Trans-Himalayan Cold Desert Region-Ladakh. Int.J.Curr.Microbiol.App.Sci. 6(3): 1996-2001. doi: https://doi.org/10.20546/ijcmas.2017.603.227 